Case 2.-In April of this year, while at the home of this patient. I notied several of his children with the dermatitis on the lands. On thorongh investigntion I found that Mrs. M. C., aged 38, wife of the patient just described, had noticed in September, 1911, that her lands were slightly sumburned and thint sle had a diarrlea at the same time. On careful rxamination I found only a slight trace of the dermatitis but the month was denuded of the mucous membrane in several plices nnd some uleers were present. Mrs. C. is the mother of nine children, ranging from 2 to 20 yenrs of age. Three of these are by lier former husbnnd, who is now dead; the other six are by the present living husband.

CAsE 3.-J. T., aged 20, oldest clild by the first husband of Patient 2, showed a symmetrical dermatitis on both hauds, denuded mucous membrane in mouth and history of dinrrien. Je nppenred well nourisled, but sulfered from insomnia. He first noticed the symptonis described in March, 1011, but all of these cleared up so he did not see any doctor. In lebrunry, 1012 , the symptoms returned.

Case 4.-R. T., aged 18, was very anemic and poorly nour. ished; the symptoms were the sume as his brother's, except much more marked; they were noticed first in May, 1911, and then ngnin in April, 1912.

Cast: 5.-S. T., n girl, uged 17, showed no lesions on hands at this time, though month showed denuded arens; there wh

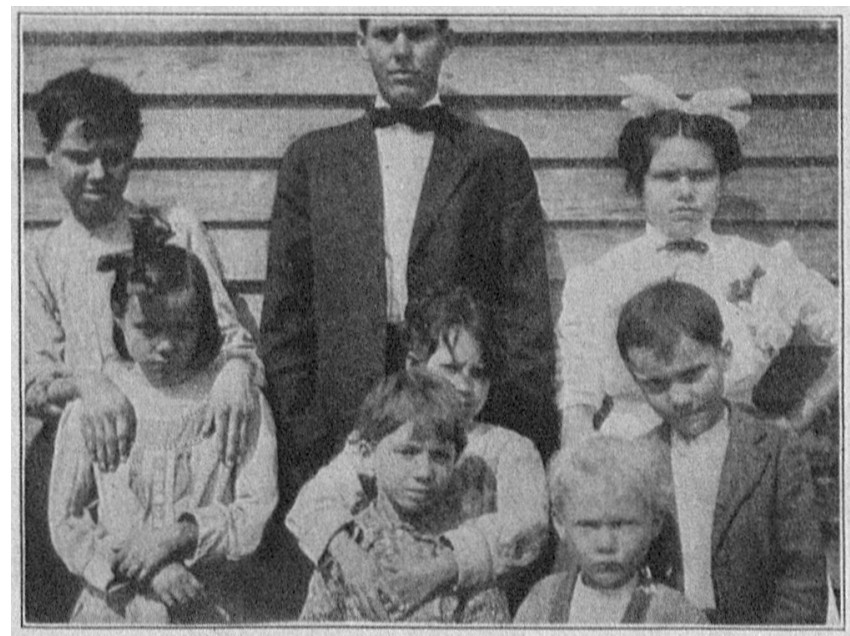

Eight chlldren, of one famlly, all sufferlng from pellagra. The pnicuts, who also huve the discnse, objected to having their picture's lakeu.

a history of diarrhea. Patient says her liands were like licr brother's, but they got well without any treatment. Slight dirrihen wus still present.

CASE 6.-I. C., girl, oldest child by second husband, was examined next. She showed a marned dermatitis on both hands, both cheeks, diarrhen and diaensed mucous membrane in mouth. Physienl examination slowed a very poorly nourished child with a mitral regurgitunt lesion. She first noticod pellngra symptoms in April, 1912.

CAsE 7.-M. C., a girl, nged 9, with dermutitis on hands and fince, very marked, gave a listory of diarrhea, and month sliowed a disensed mucous membrane. Symptoms were first noticed in April, 1912.

Cask: 8.-Next, R. C., a boy, nged 8, showed dermatitis on both hnnds, mucous membrane of month diseased and his. tory of dinurhea. Symptoms were first noticed in April, 1912.

CAsE 9.-M. C., a boy, aged 6 , showed same condition and same history as those of the previous putient.

Case 10.-R. C., aged 4, showed murked dermutitis on both lunds; he gave history of diarrhen, and mucous membrane of month was sore.

Baby C., aged 2, showed no symptoms as jet.

The three youngest ehildren have recently lind mensles, the older ones having had it previously. Examination for hook-
Worm showed nll but the mother and baby infected, also showed L. C. inferted with Ascaris lumbricoides.

Treatment.-A specimen of the corn-meal used was examined and found to be unfit for human consumption. The patients said that on several occasions the meal bought would be so moldy before it was used up that they fed it to the stock on the plince. Corn in all forms was prohibited to theso people, intestinal antiseptics were prescribed and at present (May, 1912), nll are doing nicely. R. C., however, has run away from liome nud gone to Winoker, Ga.

I wish to thunk Dr. T. F. Abererombie, of Atlanta, and Dr. M. M. Johnson, of Waycross, Ga., for courtesies showed me with these putients. Both of these physicinns went to see the patients with me and confirmed the dingnosis.

Gilmore Strect.

\section{A SIMPLE AND PRECISE METHOD OF DIFFERENTIAL LEUKOCYTS COUNTING WHERE THE WHITE CELLS ARE GREATLY INCREASED}

\section{Pinlip Atlee Sileaff, M.D., Pinladelmima}

In a recent casc of splenomyclogenous leukemia in which the leukocytes appronched 350,000 per c.mm. the great abundance of white cells in the stained sprend made an accurate dilferential count almost impossible. After some delay, however, the task was easily and accurately carried out by cutting a square from the end of a micros'opic slide of just the exact size to fit within the eyepiece and rest on its diuphrngm.

With a glarier's dinmond, and by most deliente pressure, four lines were ruled parnllel with each side of the squnre and forming a small square in its center. This, when pluced in the eyepiece, the lines being down, gave the outline of a small square on the stained spread and within the usual round field and permitted the ensy and accurate counting and classification of cells within its borders, the slide being moved 10 include a new lot in proximity to the first, and the operation repented as often as necessary until the total number of cells required for the count has been mide.

4008 Baring Strcet.

\section{Special Article}

\section{TYPHOID FEVER IN ST. CHARLES}

\section{[By Our Special Commissioner]}

St. Charles, Illinois, is a town with about 4,500 inhabitants (population 1910, 4,046) located 40 miles west of Chicago.

Sixty cases of typhoid were reported to the St. Charles health department during the eight months preceding May, 1912, or approximately one case for every seventyfive inhabitants.

Prior to the recent outbreak no cases had been reported to the henlth department since $190 \%$, in which year six cases were recorded. On inquiry among the physicians in the city it was found that a few cases had been olserved during the intervening years, but that they had attracted no particular attention and had not been reported to the health officer.

Geographically St. Charles is a compact town lying on both banks of the Fox River. The river divides the city into an eastern and a somewhat smaller western section. T'hese two divisions constitute the main part of the town. A short distance west of the western section is a settlement of recent Belgian immigrants connected with the business district by a single rond. In this isolated settlement, composed of about 150 people, the first case of typhoid appeared about Oct. 18, 1911. 'This case was 